\title{
KONTRIBUSI LINGKUNGAN KERJA, PERILAKU KEPEMIMPINAN DAN MOTIVASI KERJA TERHADAP KINERJA PEGAWAI BALAI WILAYAH SUNGAI SULAWESI
}

\author{
Adnan Hakim \\ Fakultas Ekonomi dan Bisnis Universitas Halu Oleo (UHO) Kendari \\ E-Mail: adnanhakim25@yahoo.co.id
}

\begin{abstract}
This study aimed to determine the contribution of the work environment, leadership behaviors and work motivation, either partially or simultaneously on employee performance. The approach used is causality between variables with explanatory method. Samples are 130 respondents, taken in a cluster based on education level with a percentage of $50 \%$. Of these only 115 respondents who declared eligible for further analysis. The analytical method used in this research is multiple linear regression analysis. The research found that, the work environment, leadership behaviors and work motivation partially and simultaneously have a positive and significant impact in improving employee performance. These findings implies that, in order to improve employee performance it is necessary to improve the work environment, leadership behaviors and work motivation. If these three variables increased or improved the performance of employees may be increased to a better direction.
\end{abstract}

Keywords: Work Environment, Behavior Leadership, Work Motivation, Employee Performance.

Abstrak: Penelitian ini dimaksudkan untuk mengetahui besarnya kontribusi lingkungan kerja, perilaku kepemimpinan serta motivasi kerja, baik secara parsial maupun secara simultan terhadap prestasi kerja pegawai. Pendekatan yang digunakan dalam penelitian ini adalah kuantitatif bersifat korelasional. Sampel yang digunakan sebanyak 130 orang responden, yang diambil secara klaster berdasarkan tingkat pendidikan dengan metode persentase sebanyak 50\%. Dari jumlah tersebut hanya sebanyak 115 responden yang dinyatakan layak untuk analisis selanjutnya. Metode analisis yang digunakan dalam penelitian ini adalah analisis regresi linear berganda. Hasil penelitian menemukan bahwa, lingkungan kerja, perilaku kepemimpinan dan motivasi kerja secara parsial maupun secara simultan mempunyai pengaruh positif dan signifikan dalam meningkatkan prestasi kerja pegawai. Hasil temuan ini mengandung makna bahwa, untuk meningkatkan prestasi kerja pegawai maka perlu memperbaiki lingkungan kerja, perilaku kepemimpinan serta motivasi kerja. Jika ketiga variabel tersebut ditingkatkan atau diperbaiki maka prestasi kerja pegawai dapat meningkat kearah yang lebih dari keadaan sebelumnya.

Kata kunci: Lingkungan Kerja, Perilaku Kepemimpinan Serta Prestasi Kerja.

\section{PENDAHULUAN}

Eksistensi sumber daya manusia atau pegawai dalam suatu organisasi memegang peranan penting dalam rangka mencapai tujuan organisasi sesuai dengan visi dan misi yang telah ditentukan sebelumnya. Karena secanggih apapun sumber daya yang tersedia bagi 
organisasi, jika tidak didukung oleh sumber daya manusia atau pegawai yang mempunyai kompetensi untuk memanfaatkan sumber daya organisasi maka tujuan organisasi tidak dapat dicapai secara optimal. Tujuan dan sasaran organisasi tidak dapat dikelola dengan baik, apabila semua pihak yang terlibat dalam organisasi tidak memiliki etos kerja yang tinggi untuk mencapai kinerja yang unggul.

Kinerja (performance) merupakan hasil kerja yang dapat dicapai oleh seseorang atau sekelompok orang dalam suatu organisasi, sesuai dengan wewenangnya dan tanggung jawabnya masing-masing untuk mencapai tujuan organisasi bersangkutan secara legal, tidak melanggar hukum, dan sesuai dengan moral maupun etika (Prawirosentoro, 2000). Dengan demikian maka dapat dikatakan bahwa, seseorang atau pegawai yang bekerja dalam suatu organisasi diharapkan untuk bekerja dengan baik agar dapat mencapai kinerja yang tinggi, dan pada akhirnya dapat mencapai tujuan organisasi.

Untuk meningkatkan kinerja pegawai maka ada beberapa faktor yang mempengaruhi pencapaian kinerja adalah faktor kemampuan (ability) dan faktor motivasi (motivation) (Mangkunegara, 2005), sedangkan Lorsch \& Laurence dalam Wibowo (2007) menyatakan bahwa kinerja merupakan fungsi atribut individu, organisasi dan lingkungan. Dengan demikian berarti salah satu faktor yang menentukan kinerja seorang pegawai adalah lingkungan dimana pegawai tersebut bekerja.

Lingkungan tempat para pegawai menjalankan tugas dan tanggungjawab yang dibebankan kepadanya disebut dengan lingkungan kerja. Lingkungan kerja adalah segala sesuatu yang ada dilingkungan para pekerjaan dan yang dapat mempengaruhi dirinya dalam menjalankan tugas-tugas yang dibebankan kepadanya (Nitisemito, 2003). Ini berarti bahwa, lingkungan kerja yang baik dapat memberikan kenyamanan kepada pegawai dalam melaksanakan tugas yang diembankan kepadanya oleh organisasi. Dukungan lingkungan kerja baik secara fisik maupun non fisik (Sedarmayanti, 2001) merupakan dambaan semua pegawai agar dapat bekerja dengan baik. Menurut Budiyanto (2008) bahwa lingkungan kerja menjadi salah satu determinan penting bagi pembentukan prestasi kerja atau dengan kata lain bahwa, prestasi kerja dipengaruhi oleh lingkungan kerja, sedangkan Robbins (1996) menyatakan bahwa lingkungan kerja adalah faktor ekstrinsik yang berpengaruh terhadap peningkatan aktivitas kerja. Kemudian William (1996) menyatakan bahwa ada tiga faktor yang mempengaruhi kinerja pegawai berdasarkan lingkungan kerja, yaitu faktor hubungan antara pegawai, faktor individu dan faktor-faktor luar (eksternal).

Secara konseptual telah dikemukakan oleh Laurence dalam Wibowo (2007) bahwa, salah satu faktor yang menjadi atribut penentu kinerja adalah organisasi. Setiap organisasi dapat berjalan dengan baik apabila ada dukungan dari pemimpin organisasi yang bersangkutan. Wujud dukungan pimpinan organisasi terhadap pegawai dapat dilihat dari perilaku kepemimpinan yang diterapkan dalam organisasi. Kepemimpinan merupakan kemampuan untuk mempengaruhi sekelompok anggota agar bekerja mencapai tujuan dan sasaran yang telah ditetapkan (Robbins, 2001), sedangkan Gibson (2002) mengemukakan bahwa kepemimpinan sebagai kemampuan untuk mempengaruhi motivasi atau kompetisi individu-individu lainnya dalam suatu kelompok. Selanjutnya, Sujak (2000) menyatakan bahwa bila pemimpin memberi dorongan yang lebih besar terhadap pemenuhan harapan bawahan, maka semakin besar prestasi yang akan diperoleh para bawahannya. Dengan demikian maka dapat dikatakan bahwa perilaku kepemimpinan mempunyai kontribusi dalam meningkatkan kinerja pegawai. 
Kepemimpinan merupakan kemampuan yang dimiliki oleh seorang pemimpin dalam mengendalikan dan mengarahkan bawahannya. Jadi perilaku kepemimpinan merupakan pola tindak yang diterapkan seorang pemimpin dalam membimbing dan mengarahkan bawahannya. Hal ini dapat dilihat dari perilaku kepemimpinan ketika memberikan instruktif, konsultatif, partisipasi serta perilaku delegatif terhadap bawahannya berkaitan dengan tugas yang telah diberikan kepadanya. Perilaku tersebut diimplementasikan oleh pemimpin agar bawahannya dapat bekerja secara produktif untuk mencapai tujuan organisasi. Dengan demikian maka dapat dikatakan bahwa kepemimpinan adalah cara seseorang pemimpin mempengaruhi perilaku bawahannya agar mau bekerja sama dan bekerja secara produktif untuk mencapai tujuan organisasi (Hasibuan, 2008). Kemudian Siagian (2004) mengungkapkan bahwa pemimpin yang efektif adalah pimpinan yang mampu menunjukkan jalan yang dapat ditempuh oleh bawahan sehingga gerak dari posisi sekarang ke posisi yang diinginkan di masa yang akan datang dapat berlangsung lancar sehingga produktivitas dapat tercapai, sedangkan Hasibuan (2001) menyatakan bahwa efektivitas para bawahan sebagian besar ditentukan oleh efektivitas kepemimpinan seorang pemimpin. Dengan demikian berarti perilaku kepemimpinan dapat mempengaruhi kinerja karyawan suatu orgnisasi.

Selain faktor lingkungan kerja dan perilaku kepemimpinan yang dapat mempengaruhi kinerja seseorang atau pegawai dalam suatu organisasi, tentu masih banyak faktor-faktor lainnya, namun menurut Mangkunegara (2005) bahwa yang mempengaruhi pencapaian kinerja adalah faktor kemampuan dan faktor motivasi. Motivasi adalah konsep yang menguraikan tentang kekuatan-kekuatan yang ada di dalam diri karyawan yang memulai dan mengarahkan perilaku (Gibson, 1985). Hal senada dikemukakan oleh Widjaja (1986) bahwa motivasi sebagai kekuatan baik dari dalam maupun dari luar yang mendorong seseorang untuk mencapai tujuan tertentu yang telah ditetapkan sebelumnya. Apabila motivasi tersebut diimplementasikan dalam dunia kerja maka dapat menjadi sumber kekuatan atau pendorong seseorang untuk meraih kinerja yang baik, sebagaimana dikemukakan oleh Amstrong (1994) bahwa meningkatkan motivasi dapat menghasilkan lebih banyak usaha yang diwujudkan dalam bentuk prestasi kerja.

Untuk merealisasikan tujuan organisasi maka diperlukan sumber daya manusia yang senantiasa berorientasi meningkatkan kinerja. Kinerja pegawai dipengaruhi oleh beberapa faktor, diantaranya adalah lingkungan kerja, perilaku kepemimpinan dan motivasi kerja. Kondisi faktor-faktor tersebut disetiap organisasi tentu tidak sama, demikian juga dilihat dari sisi kualitas sumber daya manusia tidak sama. Hal ini juga dirasakan oleh organisasi Balai Wilayah Sungai Sulawesi, sehingga yang menjadi permasalahan dalam penelitian ini adalah : apakah faktor lingkungan kerja, perilaku kepemimpinan dan motivasi kerja mempunyai pengaruh positif dan signifikan secara parsial dan secara simultan (bersamasama) dalam meningkatkan kinerja pegawai di Balai Wilayah Sungai Sulawesi.

Penelitian ini bertujuan untuk menganalisis dan mengetahui besarnya kontribusi secara parsial lingkungan kerja, perilaku kepemimpinan dan motivasi kerja terhadap peningkatan kinerja pegawai di Balai Wilayah Sungai Sulawesi. Tujuan berikutnya adalah untuk menganalisis dan mengetahui besarnya kontribusi lingkungan kerja, perilaku kepemimpinan dan motivasi kerja secara simultan dalam meningkatkan kinerja pegawai di Balai Wilayah Sungai Sulawesi. Dari hasil penelitian ini diharapkan dapat bermanfaat sebagai sumber masukan bagi pengembangan ilmu pengetahuan dibidang sumber daya manusia dan perilaku organisasi, dan hasil penelitian inipun diharapkan dapat memberi manfaat bagi dunia praktis sebagai sumber informasi dalam mengambil kebijakan agar 
kinerja pegawai menjadi semakin baik sehingga dapat mengantarkan organisasi yang memiliki dayasaing tinggi.

\section{KAJIAN TEORI}

Penelitian ini menfokuskan pada kausalitas antara variabel lingkungan kerja, perilaku kepemimpinan dan motivasi kerja terhadap kinerja pegawai. Kinerja adalah kontribusi individu baik positif maupun negatif yang diberikan individu pada organisasi (Ivancevich, 2008). Kinerja individu merupakan fondasi bagi kinerja organisasi. Oleh karena itu, untuk menciptakan manajemen yang efektif, memahami kinerja individu sangat penting (Noor, 2013). Ini berarti bahwa untuk meningkatkan kinerja organisasi maka diperlukan dukungan kinerja individu atau pengawai yang terlibat di dalam organisasi tersebut.

Kinerja. Menurut Robbins (2009) bahwa kinerja seseorang sangat dipengaruhi oleh faktor kemampuan dan motivasi serta kesempatan, sedangkan Noor (2013) menyatakan bahwa untuk meningkatkan kinerja pegawai, secara teoritis ada tiga kelompok yang mempengaruhinya yaitu: variabel individu, psikologis dan organisasi. Lorsch \& Laurence dalam Wibowo (2007) menyatakan bahwa kinerja merupakan fungsi atribut individu, organisasi dan lingkungan. Dari uraian tersebut diperoleh gambaran bahwa, faktor lingkungan kerja mempunyai kontribusi dalam membentuk kinerja pegawai. Lingkungan kerja adalah segala sesuatu yang ada dilingkungan para pekerjaan dan yang dapat mempengaruhi dirinya dalam menjalankan tugas-tugas yang dibebankan kepadanya (Nitisemito, 2003).

Lingkungan. Robbins (1996) menyatakan bahwa lingkungan kerja adalah faktor ekstrinsik yang berpengaruh terhadap peningkatan aktivitas kerja. Dengan demikian maka dapat dikemukakan bahwa lingkungan kerja mempunyai kontribusi dalam menigkatkan kinerja pegawai. Seperti yang disampaikan oleh Budiyanto (2008) bahwa lingkungan kerja menjadi salah satu determinan penting bagi pembentukan prestasi kerja atau dengan kata lain bahwa, prestasi kerja dipengaruhi oleh lingkungan kerja. Kemudian William (1996) menyatakan bahwa ada tiga faktor yang mempengaruhi kinerja pegawai berdasarkan lingkungan kerja, yaitu faktor hubungan antar pegawai (hubungan antar manajer dengan pegawai, faktor fisik dan kondisi kerja, hubungan sosial diantara pegawai, sugesti dari teman kerja serta emosi dan situasi), faktor individu (sikap orang terhadap pekerjaannya, umur orang sewaktu bekerja dan jenis kelamin), faktor-faktor luar (keadaan keluarga pegawai, kebutuhan rekreasi dan pendidikan).

Berdasarkan uraian tersebut bahwa lingkungan kerja perlu ditata dan difasilitasi dengan baik agar pegawai dapat betah bekerja, sebagaimana dikemukakan oleh Mahmudi (2005) bahwa penerapan lingkungan kerja yang sesuai, yang menyenangkan dan memberikan tingkat kebetahan merupakan syarat yang mutlak untuk dipenuhi. Hubungan antara konsep lingkungan kerja dengan kinerja pegawai telah dikaji oleh beberapa peneliti terdahulu dan membuktikan bahwa, lingkungan kerja mempunyai pengaruh yang signifikan dalam meningkatkan kinerja pegawai (Pambahako, 2009; Hamid, 2013 dan temuan Naharuddin \& Sadegi (2013) yang menyatakan bahwa lingkungan kerja fisik mempunyai hubungan yang signifikan terhadap kinerja pegawai. Kemudian Vesmagita (2015); Damayanti (2014) dalam kajiannya menemukan bahwa, lingkungan kerja tidak mempunyai pengaruh yang signifikan dalam meningkatkan kinerja pegawai. 
Kinerja merupakan hasil kerja yang telah dicapai oleh pegawai dalam melaksanakan tugas dan tanggungjawab yang dibebankan kepadanya. Hasil kerja tersebut dapat diperoleh dengan baik tidak terlepas dari adanya dukungan lingkungan kerja dan bimbingan dan arahan pimpinan organisasi. Oleh karena itu, seorang pemimpin yang ingin sukses dalam kepemimpinannya maka harus memiliki kemampuan kepemimpinan yang dapat diterima oleh semua anggota organisasi atau pegawai yang ada dalam lingkungan organisasi tersebut. Menurut Rivai (2004) bahwa pemimpin menjalin hubungan kerja yang efektif melalui kerja sama dengan orang-orang yang dipimpinnya. Kerja sama antara bawahan dengan atasan dapat berjalan dengan baik apabila ada dukungan perilaku kepemimpinan yang dapat memotivasi pegawai untuk bekerja dengan baik.

Kepemimpinan. Perilaku kepemimpinan dapat diwujudkan melalui kegiatan dalam pemberian instruksi, konsultatif, partisipasi serta perilaku delegatif (Wahjosumidjo, 2001). Pelaksanaan kegiatan tersebut hendaknya dapat tercipta hubungan kerja yang harmonis antara pemimpin dengan yang dipimpin, seperti dinyatakan oleh Hasibuan (2001) bahwa efektivitas para bawahan sebagian besar ditentukan oleh efektivitas kepemimpinan seorang pemimpin, sedangkan Siagian (2002) menyatakan bahwa perilaku kepemimpinan adalah norma perilaku yang digunakan seorang pemimpin pada saat ia mencoba mempengaruhi perilaku bawahannya di dalam organisasi. Lebih lanjut dikemukakan bahwa perilaku kepemimpinan yang terdapat dalam suatu organisasi memainkan peranan yang sangat dominan dalam keberhasilan organisasi tersebut dalam menyelenggarakan berbagai kegiatannya terutama terlihat dalam meningkatkan prestasi kerja para pegawainya.

Sujak (2000) menyatakan bahwa bila pemimpin memberi dorongan yang lebih besar terhadap pemenuhan harapan bawahan, maka semakin besar prestasi yang akan diperoleh para bawahannya. Dengan demikian berarti perilaku kepemimpinan dengan kinerja pegawai mempunyai korelasi yang saling menunjang. Hal tersebut telah dibuktikan oleh Hamid (2013); Kurniawati (2008) dan Tampubolon (2007) bahwa perilaku kepemimpinan mempunyai pengaruh yang signifikan terhadap prestasi kerja pegawai, sedangkan Roscahyo (2013) menemukan bahwa gaya kepemimpinan berpengaruh secara signifikan terhadap kinerja pegawai. Kemudian temuan Samsuri, Margono, dan Sugandi (2014) bahwa penerapan gaya kepemimpinan sebagai upaya peningkatkan kerja yang optimal dan mampu mendayagunakan potensi Sumber Daya Manusia yang dimiliki oleh pegawai guna menciptakan tujuan organisasi.

Selain faktor lingkungan kerja dan perilaku kepemimpinan yang mempengaruhi kinerja pegawai maka motivasi merupakan salah satu faktor yang mempengaruhi pencapaian kinerja (Mangkunegara, 2005). Motivasi adalah sekelompok pendorong yang mempunyai ciri-ciri sebagai berikut: berasal baik dari dalam maupun dari luar individu, dapat menimbulkan perilaku kerja, dan dapat menentukan bentuk, tujuan, intensitas, dan lamanya perilaku bekerja tadi. Dengan demikian berarti motivasi seseorang dalam bekerja dapat mempengaruhi keberhasilan dalam menjalankan tugas yang dibebankan kepadanya. Menurut Gibson dalam Mangkunegara (2005) bahwa salah satu variabel yang mempengaruhi prestasi kerja adalah variabel psikologis, dan termasuk salah satu didalamnya adalah motivasi, sedangkan Syamsi (2003) menyatakan bahwa, salah satu aspek yang penting dalam mempertahankan dan menjamin prestasi kerja adalah bagaimana pemimpin mampu mempertahankan dan menjamin motivasi kerja melalui pemenuhan kebutuhan bawahannya. 
Motivasi. Berdasarkan uraian tersebut maka dapat dikatakan bahwa, motivasi kerja mempunyai hubungan dengan kinerja seseorang atau pegawai dalam suatu organisasi. Hubungan antara konsep motivasi kerja dengan kinerja pegawai telah banyak dikaji oleh peneliti terdahulu, seperti McLeland (1961) bahwa ada hubungan yang positif antara motivasi berprestasi dengan kinerja. Hasil penelitian ini mendapat dukungan dari Hamid (2013); Jayaweera (2015); Narmodo (2009); Darmayanti (2014) bahwa motivasi kerja mempunyai pengaruh terhadap kinerja.

Berdasarkan ulasan tersebut maka dapat diduga bahwa secara parsial lingkungan kerja, perilaku kepemimpinan dan motivasi kerja mempunyai kontribusi yang positif dan signifikan dalam meningkatkan kinerja pegawai. Demikian juga secara simultan variabel lingkungan kerja, perilaku kepemimpinan dan motivasi kerja mempunyai kontribusi yang positif dan signifikan dalam meningkatkan kinerja pegawai. Hubungan antara konsep lingkungan kerja, perilaku kerja dan motivasi kerja terhadap kinerja pegawai dilingkungan Balai Wilayah Sungai Sulawesi dapat digambarkan dalam suatu model penelitian sebagai berikut :

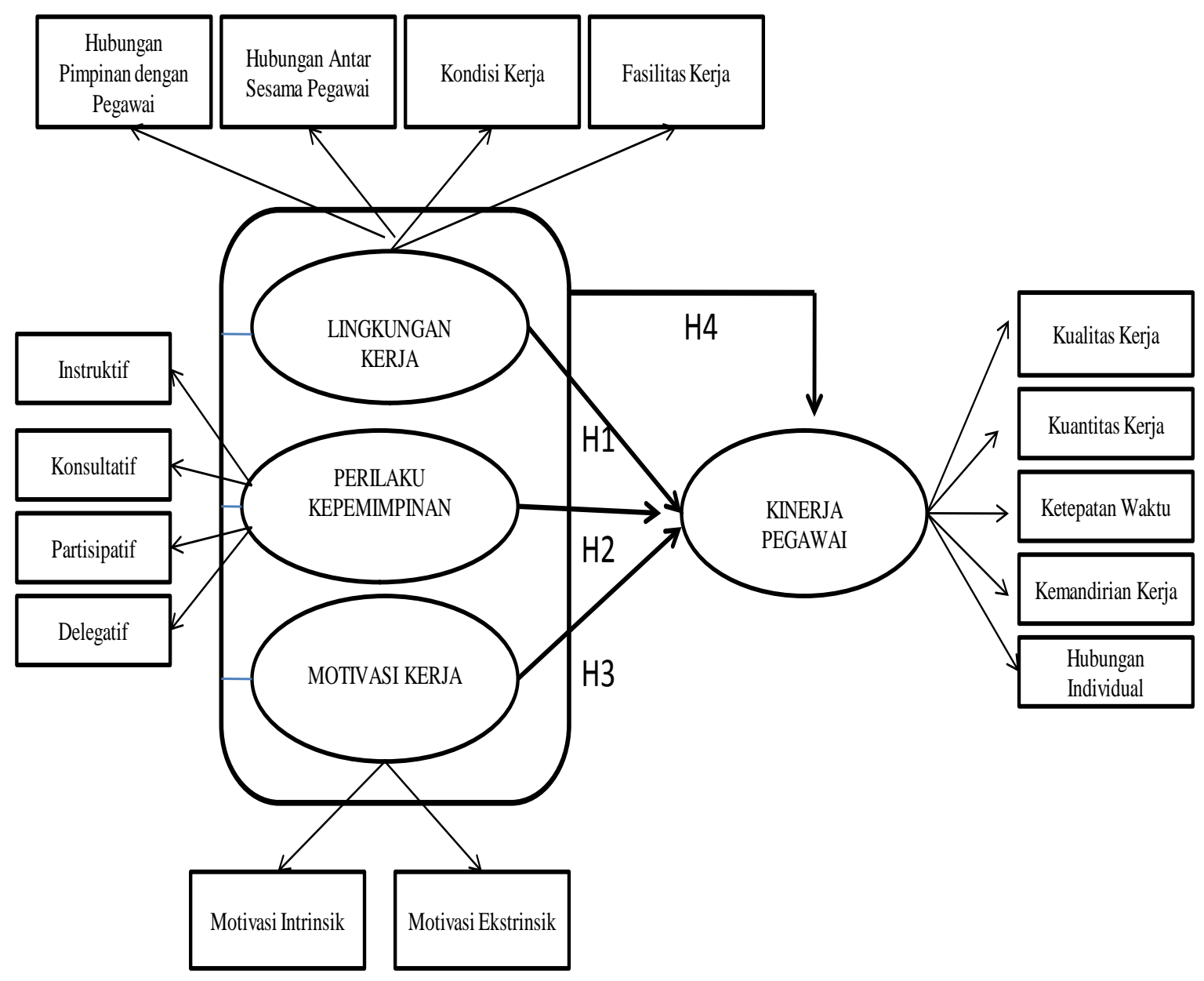

Gambar 1. Model Kerangka Konsep Penelitian 


\section{METODE}

Penelitian ini menggunakan pendekatan eksplanatif kausalitas, yaitu penelitian yang bertujuan untuk mengetahui pengaruh antara dua variabel atau lebih dengan cara meneliti hubungan kausal diantara variabel tersebut (Sugiyono, 2005). Dalam penelitian ini dirancang untuk mengetahui kontribusi lingkungan kerja, perilaku kepemimpinan, motivasi kerja terhadap kinerja pegawai. Unit analisis yang mejadi sasaran adalah semua pegawai yang telah bekerja dalam organisasi ini sebanyak 159 orang. Oleh karena populasi terlalu besar maka diambil data secara kluster untuk menentukan jumlah sampel sasaran berdasarkan tingkat pendidikan SMA/Sederajat sampai Magister dengan metode presentasi sebanyak 50\%, sehingga sampel sasaran sebesar 130 orang responden. Untuk memperoleh data lapangan maka digunakan kuesioner yang diedarkan secara langsung ke responden sasaran.

Data yang digunakan dalam penelitian ini adalah data primer yang dikumpulkan secara langsung ke responden sasaran dengan menggunakan kuesioner yang bersifat tertutup. Sebelum kuesioner diedarkan secara umum maka terlebih dahulu dilakukan pengujian instrumen guna mengetahui tingkat validitas \& reliabilitas semua indikator variabel yang membentuk masing-masing variabel penelitian, yang diukur dengan menggunakan skala likert lima tingkatan. Standar penilaian uji validitas adalah apabila nilai $\mathrm{r}>0,30$ atau sig $<0,05$ dinyatakan valid, sebaliknya apabila nilai $\mathrm{r}<0,30$ atau sig $>$ 0,05 dinyatakan invalid. Kemudian uji reliabilitas menggunakan pedoman yaitu, apabila nilai alpha crombach $>0,60$ maka dikatakan reliabel, sebaliknya apabila nilai alpha crombach $<0,60$ maka dikatakan in reliabel.

Berdasarkan hasil uji validitas terhadap semua variabel indikator dari masingmasing variabel penelitian dinyatakan valid karena nilai $r>0,30$ atau sig $<0,05$. Demikian juga terhadap uji reliabilitas dinyatakan sudah reliabel karena semua variabel indikator yang membentuk variabel penelitian mempunyai nilai $\alpha$ crombach $>0,60$.

Variabel yang diamati dalam penelitian ini dibagi atas dua kelompok, yaitu: lingkungan kerja, perilaku kepemimpinan dan motivasi kerja masuk dalam variabel independen, sedangkan kinerja pegawai merupakan variabel dependen. Lingkungan kerja merupakan situasi atau keadaan tempat dimana pegawai bekerja (Robbins, 2001), yang dibentuk oleh indikator variabel: (a) Hubungan antara pegawai dengan pimpinan meliputi kelancaran hubungan, pemberian perhatian dan arahan dari pimpinan; (b) Hubungan antar sesama pegawai merupakan kegiatan yang dilakukan untuk memelihara hubungan dengan sesama rekan kerja secara baik dengan indikator: hubungan sesama pegawai yang harmonis, keakraban antar pegawai dan sikap ramah sesama pegawai; (c) Kondisi kerja adalah suasana kondisi ditempat pegawai bekerja, yang diukur dengan kondisi penerangan, suhu udara, kenyaman dan keamanan ruangan kerja; (d) Fasilitas kantor adalah segala sesuatu yang diperlukan guna mendukung terlaksananya pekerjaan dengan baik, meliputi, peralatan kerja dan bahan, perlengkapan serta ketersediaan fasilitas sosial.

Perilaku kepemimpinan adalah perilaku pimpinan dalam menjalankan kepemimpinanya yang dapat diamati melalui perilaku instruktif, konsultatif, perilaku partisipatif, serta delegatif (Wahjosumidjo, 200; Ivancevich, 2008). Perilaku instruktif merupakan tanggapan responden terhadap perilaku pimpinan dalam melakukan komunikasi dengan bawahan, membatasi peranan bawahan, memecahkan masalah, mengambil keputusan serta melakukan pengawasan. Perilaku konsultatif tanggapan responden terhadap perilaku pimpimpinan dalam memberikan instruksi, melakukan 
komunikasi dua arah, memberikan dukungan terhadap bawahan, mendengar keluhan bawahan, memberikan bantuan terhadap bawahan tetapi pelaksanaan keputusan tetap pada pimpinan. Perilaku partisipatif merupakan tanggapan responden terhadap perilaku pimpinan dalam melakukan kontrol atas pemecahan masalah, komunikasi yang harmonis, menerima masukan bawahan dengan baik, melibatkan bawahan dalam pengambilan keputusan. Perilaku delegatif merupakan tanggapan responden terhadap perilaku pimpinan dalam mendiskusikan masalah dengan bawahan, mendelegasikan sebagian pengambilan keputusan, mempertimbangkan kemampuan bawahan dalam melakukan delegasi wewenang.

Motivasi kerja merupakan dorongan kerja yang dimiliki oleh pegawai dalam melaksanakan semua tugas dan tanggung jawab yang diberikan kepadanya, baik berupa motivasi intrinsik maupun ekstrinsik. Luthans (2003) mengemukakan bahwa motivasi dapat diamati berdasarkan faktor dari dalam (intrinsic) dan faktor dari luar (ekstrinsic). Motivasi instrinsik adalah motivasi kerja yang bersumber dari dalam diri pegawai meliputi: keinginan untuk selalu terlibat dalam suatu pekerjaan, keinginan untuk melaksanakan tugas secara sungguh-sungguh, kesediaan untuk melaksanakan pekerjaan dengan baik, kesanggupan untuk melaksanakan pekerjaan secara tuntas, mempertanggungjawabkan semua hasil pekerjaan. Motivasi ekstrinsik adalah motivasi yang bersumber dari luar diri pegawai meliputi: dukungan pimpinan dalam pelaksanaan pekerjaan, hubungan dengan atasan yang harmonis, kejelasan pengarahan pimpinan dalam pelaksanaan pekerjaan, adanya kerjasama yang baik dengan rekan sekerja serta adanya dukungan rekan sekerja dalam pelaksanaan pekerjaan.

Kinerja pegawai merupakan hasil kerja yang telah dicapai oleh pegawai dalam melaksanakan semua tugas \& tanggungjawab yang dibebankan kepadanya. Menurut Benardin dan Rusel dalam Ruky (2002) bahwa kriteria primer yang dapat digunakan untuk mengukur kinerja seseorang adalah: quality (kualitas kerja), quantity (kuantitas kerja), timeliness (ketepatan waktu), need for supervision (kemandirian kerja), interpersonal impact (hubungan individual). Kualitas kerja merupakan hasil kerja yang telah dicapai oleh pegawai dalam melaksanakan tugas dan tanggungjawabnya berupa ketepatan dalam melaksanakan pekerjaan, ketelitian dalam bekerja, kerapian dalam bekerja serta kebersihan dalam bekerja. Kuantitas kerja merupakan jumlah hasil kerja dapat diselesaikan dengan baik oleh pegawai meliputi, volume kerja sesuai dengan target, konsisten dengan penggunaan waktu kerja. Konsistensi merupakan sikap yang dimiliki oleh pegawai dalam melaksanakan tugas dan tanggungjawabnya berupa, pengembangan kemampuan, mengikuti aturan yang berlaku, memiliki inisiatif, bersikap hati-hati dalam bekerja serta menghargai waktu dalam bekerja.

Untuk menjawab permasalahan dan sekaligus membuktikan hipotesis dalam penelitian ini maka digunakan analisis Regresi Linear Berganda yang penyelesaiannya menggunakan program SPSS dengan menggunakan komputer, sedangkan untuk mengetahui kontribusi masing-masing variabel indikator yang membentuk variabel penelitian lingkungan kerja, perilaku kepemimpinan, motivasi kerja dan kinerja pegawai digunakan analisis konfirmatori faktor, dengan kriteria apabila loading factor yang dicapai $(\lambda) \geq 0,4$, maka dianggap valid dan reliabel dalam menjelaskan atau mengukur variabel (Ferdinand, 2005). Sedangkan kriteria pengujian hipotesis digunakan standar secara parsial apabila thitung $>t_{\text {tabel }}$ atau probabilitas $\leq 0,05$ maka hipotesis diterima, sebaliknya, bila $t_{\text {hitung }}<t_{\text {tabel }}$ atau probabilitas $>0,05$ maka hipotesis ditolak. Secara simultan, bila 
$\mathrm{F}_{\text {hitung }}>\mathrm{F}_{\text {tabel }}$ atau probabilitas $\leq 0,05$ maka diterima, sebaliknya, bila $\mathrm{F}_{\text {hitung }}<\mathrm{F}_{\text {tabel }}$ atau probabilitas $>0,05$ maka maka hipotesis ditolak.

\section{HASIL DAN PEMBAHASAN}

Karakteristik Responden. Karakteristik responden yang diamati dalam penelitian ini meliputi jenis kelamin, usia, pendidikan dan masa kerja. Berdasarkan informasi yang diperoleh dari lapangan bahwa sekitar 80 orang responden adalah pria (69,57\%), dan sebanyak 35 orang responden adalah wanita ( 30,43\%). Dilihat dari kelompok usia, nampak bahwa sebagian besar atau sekitar 85 responden berada dalam kelompok usia 3140 tahun, kemudian diikuti oleh usia antara 41-50 tahun sebanyak 25 orang dan sisanya berada dalam usia diatas 50-an, dan dibawah 30-an sebanyak 3 responden. Kemudian dilihat dari jenjang pendidikan, ada sekitar 45 responden berpendidikan Sarjana, dan sekitar 60 responden berpendidikan SMA/Sederajat, dan sisanya sebanyak 5 responden berpendidikan diploma dan 5 responden berpendidikan magister. Dari 115 orang responden yang berhasil diamati nampak bahwa, ada 62 orang responden yang telah memiliki pengalaman kerja antara 16-20 tahun dan sekitar 42 orang yang mempunyai pengalaman kerja selama kurang lebih 11-15 tahun, sedangkan yang punya pengalaman dibawah 6 tahun sebanyak 6 orang dan diatas 30 tahun sebanyak 5 orang

Deskripsi Variabel Penelitian. Lingkungan kerja merupakan variabel yang dibentuk oleh empat variabel indikator meliputi; hubungan pegawai dengan pimpinan, hubungan antar sesama pegawai, kondisi kerja, fasilitas kerja. Hasil analisis konfirmatori faktor yang paling tinggi kontribusinya dalam membentuk lingkungan kerja adalah fasilitas kerja sebesar 0,965, dan yang paling rendah dalam membentuk lingkungan kerja adalah hubungan antar sesama pegawai dengan loading factor sebesar 0,940. Namun demikian dapat dikatakan bahwa semua indikator tersebut dinyatakan layak untuk digunakan sebagai faktor pembentuk lingkungan kerja karena nilai loading factor dari setiap indikator $>0,4$.

Perilaku Kepemimpinan dalam penelitian dibentuk oleh dimensi instruktif, konsultatif, perilaku patisipatif dan dimensi delegatif. Semua dimensi tersebut digunakan untuk mengukur perilaku kepemimpinan dengan menjadikan sebagai variabel indikator. Hasil uji konfirmatori faktor nampak bahwa indicator variabel delegatif mempunyai kontribusi yang paling tinggi dalam membentuk variabel perilaku kepemimpinan. Hal ini dapat dilihat dari nilai loading factor yang diperoleh sebesar 0, 964 dan yang paling rendah kontribusinya adalah konsultatif sebesar 0,953. Namun secara keseluruhan semua indikator tersebut dinyatakan dalam membentuk variabel perilaku kepemimpinan karena nilai loading factor, baik instruktif, konsultatif, perilaku partisipatif dan delegatif berada diatas standar yang disyaratkan, yaitu $>0,4$ sehingga dapat dikatakan signifikan untuk membentuk variabel tersebut.

Motivasi kerja dalam penelitian ini dibentuk oleh dua dimensi, yaitu motivasi instrinsik dan motivasi ekstrinsik. Kedua dimensi motivasi tersebut dijadikan sebagai variabel indikator, dan berdasarkan hasil analisis faktor bahwa, motivasi intrinsik dan motivasi ekstrinsik mempunyai nilai loading factor yang sama, yaitu 0,981. Dengan demikian maka dapat dikatakan bahwa kedua variabel indikator tersebut dinyatakan signifikan dalam membentuk variabel motivasi kerja karena nilai loading factor $>0,4$. 
Prestasi kerja merupakan hasil kerja yang telah dicapai oleh pegawai yang bersangkutan, yang diukur dengan variabel indikator kualitas kerja, kuantitas kerja, ketepatan waktu menyelesaikan pekerjaan, kemandirian kerja, hubungan individual. Hasil analisis faktor menunjukkan bahwa loading factor yang paling kuat dalam membentuk kinerja pegawai adalah kuantitas kerja sebesar 0,969, dan yang paling rendah memberikan kontribusi adalah ketepatan waktu dalam menyelesaikan pekerjaan dengan nilai loading factor sebesar 0,897, dan kualitas kerja sebesar 0,935 dan kemandirian kerja sebesar 0,949. Kesemua indikator tersebut dinyatakan signifikan dalam membentuk variabel kinerja pegawai karena berada di atas ketentuan yang distandarkan.

Pengujian Hipotesis. Berdasarkan hasil analisis dari masing-masing variabel penelitian dinyatakan layak dalam membentuk variabel, baik variabel independen meliputi lingkungan kerja, perilaku kepemimpinan, motivasi kerja maupun kinerja pegawai sebagai variabel dependen. Untuk menguji hipotesis dan sekaligus mencapai tujuan kajian ini maka variabel independen dihubungkan dengan variabel dependen melalui uji Regresi linear berganda, dan hasil analisisnya dapat dirangkum sebagai berikut

Tabel 1. Rangkuman hasil analisis Regresi berganda variabel Lingkungan Kerja, Perilaku Kepemimpinan, Motivasi Kerja terhadap Kinerja Pegawai

\begin{tabular}{|c|c|c|c|c|c|}
\hline \multirow[t]{2}{*}{ Model } & \multicolumn{2}{|c|}{$\begin{array}{c}\text { Unstandardized } \\
\text { Coeficients }\end{array}$} & \multirow{2}{*}{$\begin{array}{r}\text { Stndardizen } \\
\text { Coeficients } \\
\text { Beta }\end{array}$} & \multirow{2}{*}{$\begin{array}{l}\text { t- } \\
\text { hitung }\end{array}$} & \multirow[t]{2}{*}{ Significant } \\
\hline & B & $\begin{array}{l}\text { Std. } \\
\text { Error }\end{array}$ & & & \\
\hline Constant & 1.128 & 0.874 & & 1.291 & 0.200 \\
\hline Lingkungan Kerja & 0,602 & 0.105 & 0.527 & 5.747 & 0.000 \\
\hline Perilaku Kepemimpinan & 0,214 & 0.083 & 0.246 & 2.570 & 0.012 \\
\hline Motivasi Kerja & 0,329 & 0.071 & 0.226 & 4.659 & 0.000 \\
\hline $\mathrm{R}^{2}$ & & & 0.978 & & \\
\hline Adjusted R Square & & & 0.977 & & \\
\hline $\mathrm{F}_{\text {-hitung }}$ & & & 1608,871 & & \\
\hline $\begin{array}{l}\text { Significant } \\
\alpha 0,05\end{array}$ & & & 0,000 & & \\
\hline
\end{tabular}

Berdasarkan hasil análisis memperlihatkan nilai konstanta (a) sebesar 1,128, artinya bahwa ada pengaruh positif terhadap kinerja pegawai sebelum adanya perubahan lingkungan kerja, perilaku kepemimpinan, motivasi kerja. Dalam hasil análisis tersebut memperlihatkan nilai koefisien regresi (Standardized Coeficients) variabel lingkungan kerja sebesar 0,527. Ini berarti bahwa, variabel lingkungan kerja mempunyai pengaruh yang positif terhadap kinerja pegawai, dan bilamana lingkungan kerja diperbaiki sekitar 1 \% maka akan terjadi peningkatan kinerja pegawai sebesar 52,70\% dengan asumsi bahwa variabel lainnya dianggap konstan. Nilai koefisien regresi variabel perilaku kepemimpinan sebesar 0,246, artinya bahwa apabila pola perilaku kepemimpinan diperbaiki sekitar 1\%, maka akan terjadi peningkatan kinerja pegawai sebesar 24,60\%, dengan asumsi bahwa variabel lain dianggap tetap. Kemudian nilai koefisien regresi dari variabel motivasi kerja diperoleh sebesar 0,226, artinya apabila ada peningkatan motivasi kerja sebanyak 1\%, maka kinerja pegawai dapat meningkat sebesar 22,60\% dengan asumsi bahwa variabel lain dianggap tetap. 
Bertitik tolak dari rangkuman hasil análisis menunjukkan bahwa nilai koefisien determinasi yang diperoleh sebesar 0,978, artinya bahwa semua variabel independen (lingkungan kerja, perilaku kepemimpinan dan motivasi kerja mempunyai kemampuan menjelaskan dalam membentuk model sebesar 97,80\%, sedangkan sisanya sebesar 2,20\% masih berada di luar model dan tidak dimasukkan dalam kajian ini.

Hasil analisis regresi secara parsial menunjukkan bahwa, kontribusi variabel lingkungan kerja terhadap kinerja pegawai sebesar 0,602 dengan tingkat signifikansi sebesar 0,000. Hasil uji tersebut memperlihatkan bahwa, variabel lingkungan kerja mempunyai pengaruh positif dan signifikan dalam meningkatkan kinerja pegawai. Hal ini dapat dibuktikan karena nilai signifikansi sebesar 0,000 dengan tingkat kepercayaan sebesar 0,95 atau dengan $\alpha=0,05$. Dengan demikian maka dapat dikatakan bahwa nilai signifikansi $0,000<\alpha 0,05$, artinya bahwa hipotesis yang telah dikemukakan pada uraian sebelumnya dinyatakan terbukti bahwa, lingkungan kerja mempunyai pengaruh positif dan signifikan dalam meningkatkan kinerja pegawai.

Hasil analisis regresi secara parsial menunjukkan bahwa perilaku kepemimpinan mempunyai kontribusi secara positif dan signifikan dalam meningkatkan kinerja pegawai. Hal ini ditunjukkan oleh nilai signifikansi sebesar 0,012. Ini berarti bahwa nilai signifikansi sebesar 0,012 $<\alpha=0,05$ atau pada tingkat kepercayaan 0,95 atau $<\alpha=0,05$. Dengan demikian maka dapat dikatakan bahwa, perilaku kepemimpinan mempunyai kontribusi positif dan signifikan dalam meningkatkan kinerja pegawai, atau dengan kata lain bahwa hipotesis yang telah diajukan dinyatakan dapat diterima.

Berdasarkan hasil analisis sebagaimana terlihat dalam tabel 1 bahwa, motivasi kerja mempunyai nilai signifikansi sebesar 0,000, artinya bahwa variabel motivasi kerja secara parsial mempunyai kontribusi secara positif dan signifikan dalam meningkatkan kinerja pegawai. Hal ini dapat dibuktikan karena nilai signifikan sebesar $0,000<\alpha=0,05$ atau pada tingkat kepercayaan 0,95 atau $<\alpha=0,05$. Dengan demikian maka dapat dikatakan bahwa hipotesis yang telah dikemukakan sebelumnya dinyatakan diterima.

Dalam rangkuman hasil analisis model dalam table 1 memperlihatkan nilai $\mathrm{R}^{2}$ (Koefisien determinasi) sebesar 0,978 . Hal ini berarti bahwa, semua variabel independen (lingkungan kerja, perilaku kepemimpinan dan motivasi kerja) telah memberikan dukungan dalam pembentukan model sebesar 97,8\%, sedangkan sisanya sebesar 2,2\% masih berada di luar model dan tidak dimasukkan dalam kajian ini. Hasil penelitian ini dapat membuktikan bahwa variabel lingkungan kerja, perilaku kepemimpinan dan motivasi kerja secara bersama-sama atau simultan mempunyai pengaruh positif dan signifikan dalam meningkatkan kinerja pegawai. Hal ini dapat dilihat dari hasil uji statistik diperoleh nilai F-hitung sebesar 1608,871 dengan tingkat signifikansi sebesar 0,000. Jika hasil analisis tersebut dibandingkan dengan standar dengan tingkat kepercayaan 0,95 atau dengan $\alpha=0,05$, maka hasilnya adalah $F_{\text {hitung }}=1608,871>F_{\text {tabel yaitu 2,68 atau dengan }}$ nilai singnifikansi $=0,000<0,05$. Dengan demikian maka dapat dikemukakan bahwa secara simultan variabel lingkungan kerja, perilaku kepemimpinan dan motivasi kerja mempunyai pengaruh yang positif dan signifikan dalam meningkatkan kinerja pegawai, dan temuan ini sekaligus menjadi bukti bahwa hipotesis secara simultan dapat diterima kebenarannya.

Kontribusi Lingkungan Kerja Terhadap Kinerja Pegawai. Hasil penelitian menemukan bahwa lingkungan kerja yang dibentuk oleh variabel indikator hubungan pegawai dengan pimpinan (hubungan atasan dan bawahan lancar, adanya perhatian 
pimpinan, serta pemberian arahan oleh pimpinan), hubungan antar sesama pegawai (kemampuan karyawan menjalin kerja sama dengan rekan kerja, saling membantu, berkomunikasi dengan baik, memelihara suasana keakraban antar pegawai) dan kondisi kerja (ketersediaan alat penerangan, suhu udara, suasana tempat kerja dan keamanan dilingkungan kerja, serta fasilitas kantor (ketersediaan bahan kerja, sarana elektronik dan fasilitas sosial) mempunyai pengaruh positif dan signifikan dalam meningkatkan kinerja pegawai Balai Wilayah Sungai Sulawesi.

Temuan ini mengandung makna bahwa, untuk meningkatkan kinerja pegawai yang diukur berdasarkan kuantitas kerja, kualitas kerja, ketepatan waktu dalam bekerja dan kemandirian kerja serta hubungan individual maka diperlukan adanya dukungan lingkungan kerja yang baik dengan cara menciptakan suasana hubungan yang harmonis antara pegawai dengan pimpinan, antara sesama rekan kerja dan dukungan kondisi kerja yang nyaman serta ketersediaan fasilitas kerja sesuai dengan kebutuhan kerja pegawai dalam rangka meningkatkan kinerjanya. Hasil penelitian ini telah memberikan dukungan atas konsep yang telah dikemukakan oleh Budiyanto (2008) bahwa lingkungan kerja menjadi salah satu determinan penting bagi pembentukan prestasi kerja atau dengan kata lain bahwa prestasi kerja dipengaruhi oleh lingkungan kerja. Demikian juga dikemukakan oleh Robbins (1996) bahwa lingkungan kerja adalah faktor ekstrinsik yang berpengaruh terhadap peningkatan aktivitas kerja. Kemudian William (1996) menyatakan bahwa ada tiga faktor yang mempengaruhi kinerja pegawai berdasarkan lingkungan kerja, yaitu faktor hubungan antar pegawai, faktor individu dan faktor-faktor luar (eksternal). Hasil penelitian ini sekaligus dapat memperkaya temuan sebelumnya bahwa lingkungan kerja berpengaruh terhadap kinerja pegawai (Pambahako (2009); Hamid (2013). Demikian juga temuan Naharuddin \& Sadegi (2013) yang menyatakan bahwa lingkungan kerja fisik mempunyai hubungan yang signifikan terhadap kinerja pegawai. Temuan ini sekaligus menolak hasil kajian Vesmagita (2015) dan Damayanti (2014) yang menyatakan bahwa lingkungan kerja tidak mempunyai pengaruh yang signifikan dalam meningkatkan kinerja pegawai.

Kontribusi Perilaku Kepemimpinan Terhadap Kinerja Pegawai. Berdasarkan hasil penelitian ditemukan bahwa perilaku kepemimpinan mempunyai kontribusi positif dan signifikan dalam meningkatkan kinerja pegawai. Ini berarti bahwa, untuk meningkatkan kinerja pegawai dalam melaksanakan tugas dan tanggungjawabnya terutama berkaitan dengan peningkatan kuantitas kerja, kualitas kerja, ketepatan waktu dan kemandirian kerja dan hubungan individual maka diperlukan adanya dukungan dari perilaku kepemimpinan terutama berkaitan dengan perilaku instruktif, konsultatif dan partisipatif serta delegatif. Perilaku kepemimpinan tersebut ternyata dapat diimplementasikan oleh pimpinan sehingga dalam memberi dampak terhadap peningkatan kinerja pegawai dilingkungan Balai Wilayah Sungai Sulawesi.

Hasil penelitian ini ikut memperkuat konsep teori yang telah dikemukakan oleh Siagian (2002) bahwa, perilaku kepemimpinan adalah norma perilaku yang digunakan seorang pimpinan pada saat ia mencoba mempengaruhi perilaku bawahannya di dalam sebuah organisasi. Keberhasilan suatu organisasi baik sebagai keseluruhan maupun sebagai kelompok sangat tergantung pada perilaku kepemimpinan yang terdapat dalam organisasi yang bersangkutan. Lebih lanjut dikemukakan bahwa perilaku kepemimpinan yang terdapat dalam suatu organisasi memainkan peranan yang sangat dominan dalam keberhasilan organisasi tersebut dalam menyelenggarakan berbagai kegiatannya terutama 
terlihat dalam meningkatkan kinerja para pegawainya. Kemudian Sujak (2000) menyatakan bahwa bila pemimpin memberi dorongan yang lebih besar terhadap pemenuhan harapan bawahan, maka semakin besar prestasi yang akan diperoleh para bawahan. Dengan demikian berarti perilaku kepemimpinan memegang peranan penting dalam meningkatkan kinerja pegawai.

Hasil temuan tersebut ikut memberikan dukungan kepada para peneliti terdahulu yang menyatakan bahwa, perilaku kepemimpinan berpengaruh signifikan terhadap kinerja pegawai (Hamid, 2013); Kurniawati (2008); dan Tampubolong (2007). Demikian juga temuan Roscahyo (2013) bahwa gaya kepemimpinan berpengaruh secara signifikan terhadap kinerja pegawai, sedangkan Samsuri, Margono dan Sugandi (2014) menyatakan bahwa, penerapan gaya kepemimpinan sebagai upaya peningkatan kerja yang optimal dan mampu mendayagunakan potensi sumber daya manusia yang dimiliki oleh pegawai guna menciptakan tujuan organisasi.

Pengaruh Motivasi Kerja Terhadap Kinerja Pegawai. Hasil penelitian membuktikan bahwa motivasi kerja mempunyai kontribusi positif dan signifikan dalam meningkatkan kinerja pegawai. Ini berarti bahwa, untuk meningkatkan kinerja pegawai maka diperlukan adanya peningkatan motivasi kerja, baik motivasi intrinsik, seperti keinginan untuk selalu terlibat dalam suatu pekerjaan, keinginan untuk melaksanakan pekerjaan dengan baik, kesediaan untuk melaksanakan pekerjaan secara sungguh-sungguh, kesanggupan untuk melaksanakan pekerjaan, komitmen untuk melaksanakan pekerjaan maupun motivasi ekstrinsik terutama yang berkaitan dengan dukungan pimpinan dalam pelaksanaan pekerjaan, harmoni hubungan dengan atasan, kejelasan pengarahan pimpinan dalam pelaksanaan pekerjaan, kerjasama yang harmonis dengan rekan sekerja, dukungan rekan sekerja dalam pelaksanaan pekerjaan.

Hasil penelitian ini telah memberikan dukungan terhadap konsep teori yang dikemukakan oleh Gibson bahwa, salah satu variabel yang mempengaruhi prestasi kerja adalah variabel psikologis, dan termasuk salah satu didalamnya adalah motivasi, sedangkan Syamsi (2003) mengemukakan bahwa salah satu aspek yang penting dalam mempertahankan dan menjamin prestasi kerja adalah bagaimana pimpinan mampu mempertahankan dan menjamin motivasi kerja melalui pemenuhan kebutuhan bawahannya. Temuan ini sekaligus memperkuat hasil kajian terdahulu yang menyatakan bahwa ada hubungan yang positif antara motivasi berprestasi dengan kinerja (McLeland, 1961). Demikian juga hasil penelitian Jayaweera (2015); Darmayanti (2014); Hamid (2013); Narmado (2009) bahwa motivasi kerja mempunyai pengaruh terhadap kinerja pegawai.

Kontribusi Lingkungan Kerja, Perilaku Kepemimpinan dan Motivasi Kerja Terhadap Kinerja Pegawai. Penelitian ini dimaksudkan untuk mengetahui besarnya kontribusi semua variabel independen (Lingkungan kerja, Perilaku kepemimpinan dan Motivasi kerja) secara bersama-sama (simultan) terhadap peningkatan kinerja pegawai. Berdasarkan hasil penelitian menemukan bahwa, variabel lingkungan kerja, perilaku kepemimpinan dan motivasi kerja secara simultan mempunyai kontribusi yang positif dan signifikan dalam meningkatkan kinerja pegawai Balai Wilayah Sungai Sulawesi. Temuan ini mengandung makna bahwa, untuk meningkatkan kinerja pegawai baik secara kuantitatif, kualitatif maupun dari segi ketepatan waktu dalam menyelesaikan pekerjaan dan kemandirian dalam bekerja serta kemampuan dalam membangun hubungan secara individu, maka diperlukan adanya perbaikan dan peningkatan lingkungan kerja baik dari 
segi hubungan antara pimpinan dan pegawai, antara sesama pegawai maupun berkaitan dengan kondisi kerja serta ketersediaan fasilitas kerja. Diperlukan pula adanya perilaku kepemimpinan yang berorientasi untuk memberikan pengarahan dan dukungan serta keterlibatan yang harmonis antara pimpinan dengan pegawai dalam rangka meningkatkan kinerja pegawai. Selain itu, diperlukan pula adanya peningkatan motivasi kerja pegawai, baik yang bersifat intrinsik maupun ekstrinsik dalam rangka meningkatkan kinerja pegawai dilingkungan Balai Wilayah Sungai Sulawesi. Temuan ini sekaligus memberi gambaran bahwa untuk meningkatkan kinerja pegawai dalam melaksanakan tugas \& tanggung jawabnya sebagai aparatur Negara maka sangat penting adanya dukungan lingkungan kerja, perilaku kepemimpinan yang humanis serta motivasi kerja yang penuh semangat dan dedikasi yang tinggi untuk mengantarkan organisasi mencapai tujuan dan sasaran yang telah ditetapkan sebelumnya demi mencapai keunggulan daya saing yang kompetitif.

\section{PENUTUP}

Simpulan. Berdasarkan hasil penelitian maka dapat diambil beberapa kesimpulan bahwa: Lingkungan kerja, Perilaku kepemimpinan dan Motivasi kerja secara serentak atau bersama-sama dapat mempengaruhi peningkatan kinerja pegawai secara signifikan, artinya bahwa apabila kinerja pegawai diharapkan peningkatannya maka sangat diperlukan adanya dukungan dari lingkungan kerja, perilaku kepemimpinan serta motivasi kerja karyawan. Ditemukan pula bahwa lingkungan kerja, perilaku kepemimpinan dan motivasi kerja pegawai secara parsial mempunyai pengaruh yang signifikan dalam meningkatkan kinerja pegawai. Artinya bahwa, apabila diharapkan adanya peningkatan kinerja pegawai, baik dari segi kuantitas kerja, kulitas kerja, ketepatan waktu, kemandirian serta hubungan personal maka diperlukan adanya dukungan dari lingkungan kerja berupa hubungan yang harmonis antara pimpinan dan bawahan, antar sesama rekan kerja, kondisi kerja yang $\mathrm{n}$ yaman serta ketersediaan fasilitas kerja yang memadai. Selain itu, diperlukan pula dukungan perilaku kepemimpinan dalam kaitannya dengan perilaku instruksi, konsultatif, partisipatif dan perilaku delegatif. Jika perilaku kepemimpinan tersebut dapat diterima oleh pegawai secara baik, maka dapat meningkatkan kinerja pegawai, bahkan dapat menjadi motivasi bagi pegawai untuk meraih kinerja yang lebih baik. Kehadiran motivasi kerja pegawai, baik terkait dengan motivasi intrinsik maupun ekstrinsik dapat menjadi faktor pendorong bagi pegawai dalam meningkatkan kinerjanya dilingkungan Balai Wilayah Sungai Sulawesi.

Rekomendasi. Dalam penelitian ini masih dijumpai keterbatasan yang perlu diperbaiki agar dapat menunjang kinerja pegawai, terutama dari segi hubungan pegawai dengan rekan kerjanya. Oleh karena itu, perlu diciptakan \& dibangun nilai-nilai kebersamaan diantara sesama pegawai dalam lingkungan kerja yang sama. Untuk membangun etos kerja pegawai dalam melaksanakan tugasnya dengan baik, maka diperlukan adanya komunikasi yang harmonis antara pimpinan dengan bawahannya. Oleh karena itu diperlukan adanya keterbukaan pimpinan untuk lebih berperan sebagai media konsultasi yang harmonis dalam rangka meningkatkan kinerja pegawai. Pesan berikutnya disampaikan kepada pihak yang berminat untuk mendalami kajian seperti maka diperlukan adanya penelitian lanjutnya dengan memperhatikan sisi psikologi lainnya, seperti kompetensi dan etos kerja untuk diamati lebih lanjut atau melengkapi penelitian ini. 


\section{DAFTAR RUJUKAN}

Amstrong, M., (1994) A Handbook of Human Resource Management. Terjemahan Elex Media Kompotindo. Jakarta.

Bernardin, H John and Joyce E. A. Russell, (2002) Human Resource Management: An Experiential Approach, McGraw-Hill Inc.

Budiyanto, (2008) Pengaruh Kepemimpinan dan Lingkungan Kerja Terhadap Kepuasan Kerja Karyawan Pada PT. Safari Junie Texindo Industri di Boyolali, didownload dari : http.www.google.com

Damayanti. F., (2014) Pengaruh Lingkungan Kerja Dan Motivasi Terhadap Prestasi Kerjadi SMP Negeri 1 Widasari Kabupaten Indramayu. Jurnal, VI (12): 1693-7945.

Ferdinan, A., (2005) Structur Equation Modeling, Dalam Penelitian Manajemen, Aplikasi Model-Model Rumit Dalam Penelitian Untuk Tesis Maister dan Disertasi Doktor, BP UNDIP, Semarang.

Gibson, DH., (2002) Total Quality Management, (Terjemahan Fandy Tjiptono Anastasia Diana), Andy Offset, Jakarta.

Gibson, J.W., (1985) Organisasi dan Manajemen, Perilaku Struktur dan Proses (Terjemahan Agung Prihartono), Bumi Aksara. Jakarta.

Hamid, (2013) "Pengaruh Perilaku Kepemimpinan, Motivasi Kerja dan Lingkungan Kerja Terhadap Prestasi Kerja Pegawai DiRumah Sakit Umum Daerah Kabupaten Konawe Selatan”.Tesis. Program Pascasarjana Universitas Haluoleo, Kendari.

Hasibuan, (2001) Manajemen Dasar Pengantar dan Masalah. Masagung. Jakarta.

-----------, (2005) Organisasi dan Motivasi. Jakarta : Bumi Aksara. -, (2008) Organisasi dan Motivasi, Bumi Aksara. Jakarta.

Ivancevich, J., M., (2008) Human Resources Management, Edisi kesepuluh. McGraw Hill. International Inc. Singapure.

Jayaweera, T., (2015) "Impact Of Work Environmental Factors On Job Performance, Mediating Role Of Work Motivation: A Study Of Hotel Sector In England”. International Journal of Business And Management. 10 (3): 1833-3850 E-ISSN 1833-8119 Published by Canadian Center of Science and Education

Kurniawati, F., (2008) "Pengaruh Kepemimpinan dan Motivasi Kerja Terhadap Prestasi Kerja Karyawan Pada PT. Alfa Retailindo Kartasura Surakarta”, Skripsi, didownload dari http//www.google. com

Luthans, F. (2003) Organizational Behavior. McGraw-Hill, New York.

Mahmudi, (2005) Manajemen Kinerja Sektor Publik. Akademi Manajemen Perusahaan YKPN. Yogyakarta.

Mangkunegara, A.P., (2005) Manajemen Sumber Daya Manusia Perusahaan. PT. Remaja Rosdakarya. Bandung.

Maryanto, (2010) "Pengaruh Kepemimpinan dan Motivasi Terhadap Disiplin Kerja Antara Badan Perwakilan Desa (BPD) di Kecamatan Ngadirojo Kabupaten Wonogiri”, Tesis, Muhammadiyah University Press, Surakarta.

McLeland, D., C., (1961) The Achievement Motive. Irvington Publisher. New York.

Naharuddin, N., M., \& Sadegi, M., (2013) "Factors of Workplace Environment that Affect Employees Performance: A Case Study of Miyazu Malaysia”. Limkokwing University of Creative Technology International Journal Of Independent Research And Studies - Ijirs. 2 (2): 66-78, ISSN, 2226-4817; Eissn: 2304-6953. Indexing And Abstracting: Ulrich's - Global Serials Directory 
Narmodo, H., (2009) “Pengaruh Motivasi dan Disiplin Terhadap Kinerja Pegawai Badan Kepegawaian Daerah Kabupaten Wonogiri”, Tesis, Muhammadiyah University Press, Surakarta

Nitisemito, A., S., (2003) Manajemen Personalia, Ghalia Indonesia, Jakarta

Noor, J., (2013) Penelitian Ilmu Manajemen: Tinjauan Filosofis dan Praktis. Edisi Pertama. Kencana Prenada Media Group. Jakarta.

Pambahako, Y., L., (2009) "Pengaruh Lingkungan Kerja dan Promosi Jabatan Terhadap Produktivitas Kerja dan Kinerja Pada Kantor Pelayanan Pajak Pratama Kendari”, Tesis, Unhalu, Kendari.

Prawirosentono, S., (2000) Manajemen Sumber Daya Manusia Kebijakan Kinerja Karyawan. Edisi 1, BPFE, Yogyakarta.

Rivai, V., (2004) Kepemimpinan dan Perilaku Organisasi, Edisi kedua, PT. Rajawali Press Persada. Jakarta.

Robbins, S.P., Judge, T., A., (2009) Organizational Behavours, edisi ke-9, Prentice Hall International Inc. Singapura.

Robbins, S.P., (1996) Organizational Behavior, Concepts, Controversies Applications, Seventh Edition, By Prentice Hall, Inc. New York.

-------------, (2001) Pemimpin dan Kepemimpinan, Terjemahan Mar'at, Ghalia Indonesia, Jakarta.

Roscahyo, A., Prijati. (2013) Pengaruh Gaya Kepemimpinan Terhadap Kinerja Karyawan pada Rumah Sakit Siti Khodijah Sidoarjo. Jurnal Ilmu \& Riset Manajemen Vol. 2 No. 12.

Ruky, A., S., (2002) Sistem Manajemen Kinerja. di download dari :http// www.geocitios.com.

Samsuri, Margono, A., Sugandi. (2014) Pengaruh Gaya Kepemimpinan Situasional dan Disiplin Kerja terhadap Prestasi Kerja Pegawai pada Sekretariat Daerah Kabupaten Kutai Timur. E-jurnal Administrative Reform, 2 (1): 1076-1089 ISSN 2338-7637.

Sedarmayanti, (2001) Sumberdaya Manusia dan Produktivitas Kerja, Mandar Maju, Bandung.

Siagian, (2002) Teori Motivasi dan Aplikasinya. Bumi Aksara Jakarta Agung.

Sihotang, (2007) Manajemen Sumberdaya Manusia, PT. Pradnya Paramita, Jakarta.

Srimulyo, (2004) “Analisis Pengaruh Faktor-Faktor Yang Mempengaruhi Prestasi Kerja Pegawai Perpustakaan di Kotamadya Surabaya”, Tesis, di download dari :http//www.adln.lib.unair.ac.id

Sugiyono, (2005) Metode Penelitian Administrasi. Altabeta. Bandung

Sujak, A., (2000) Kepemimpinan Manajer, Rajawali

Syamsi, A., (2003) Faktor-Faktor Yang Mempengaruhi Produktivitas Karyawan, Unhas Press, Ujung Pandan

Tampubolon, B., D., (2007) “Analisis Faktor Gaya Kepemimpinan dan Faktor Etos Kerja Terhadap Kinerja Pegawai Pada Organisasi Yang Telah Menerapkan SNI 19-90012001”, Jurnal, didownload dari http//www.google. com

Vesmagita, S., (2015) "Pengaruh Komunikasi Organisasi Dan Lingkungan Kerja Terhadap Kinerja Karyawan Tetap Pada Pt. Mah Sing Indonesia”, Jurnal Ilmiah Manajemen Dan Bisnis, 1 (1), Maret 
Wahjosumidjo, (2001) Kiat Kepemimpinan Dalam Teori dan Praktek. Harapan Masa PGRI. Jakarta.

Wibowo, (2007) Managing Change, Pengantar Perubahan Manajemen, Alfabeta. Jakarta. Widjaja, A.,W., (1986) Administrasi Kepegawaian Suatu Pengantar. PT. Raja Grafindo Persada. Jakarta.

William, W., B.,(1996) Human Resources and Personal Management, Fifth Edition, Mc. Graw Hill, Inc. Singapore. 